\title{
ABBREVIATIONS AND SOURCES
}

\section{General Abbreviations}

an. $=$ animate

aux. $=$ auxiliary

g. = generic aspect

gen. $=$ genitive case

imp. $=$ imperative

inan. $=$ inanimate

intr. $=$ intransitive

n. $=$ noun

p. $=$ particular aspect

$\mathrm{pl} .=$ plural

poss. $=$ possessed

sg. $=$ singular

tr. $=$ transitive

voc. $=$ vocative case

Proto-Wintun (PW)

$\mathrm{V}=$ unidentified vowel

$\mathrm{C}=$ unidentified consonant

Hyphens in PW forms indicate separately reconstructed morphemes.

Wintu (W)

W items unmarked as to source are from Pitkin 1984, 1985 and my own fieldnotes. Starred forms listed under W are pre-Wintu reconstructions from Pitkin 1985. $\mathrm{E}$ and $\mathrm{O}$ are morphophonemes representing the alternations $\mathrm{e} / \mathrm{i}$ and $\mathrm{o} / \mathrm{u}$, respectively. 
Other sources are indicated as follows:

$\mathrm{C}=$ Curtin 1898

$\mathrm{DL}=$ texts published in translation by Demetracopoulou [Lee] and Du Bois 1932 and Du Bois and Demetracopoulou [Lee] 1931 and microfilms of the Wintu versions of these texts housed at the Survey of California and Other Indian Languages, Department of Linguistics, University of California, Berkeley

$M=$ Merriam 1903-1931

\section{Nomlaki (N)}

Sources are indicated following $\mathrm{N}$ as follows:

$\mathrm{B}=$ Barrett 1908

$\mathrm{BP}=$ Broadbent and Pitkin 1964

BW $=$ Blankenship and Wenger 1978

$\mathrm{C}=$ Curtis 1924

DK $=$ Dixon and Kroeber 1907

$\mathrm{G}=$ Goldsmith 1951

$\mathrm{H}=$ Hill 1971

$\mathrm{Ha}=$ Hale 1846

$\mathrm{J}=$ Johnson in Schoolcraft 1853/1860

$\mathrm{K}=$ Kroeber 1932

T-M = Merriam 1903-1931, "Upper Thoms Creek Nomlaki"

G-M = Merriam's materials entitled "Nom-lak'-ke Rancherias between Elder Creek and Grindstone Creek," and "Grindstone Creek field check list"

Noe-W = Whistler 1980, "Noema" Nomlaki

$\mathrm{P}=$ Powers 1877 (Chapter XXV, The Wintun)

PS $=$ Pitkin and Shipley 1958

$\mathrm{S}=$ Swadesh ca. 1950

SS $=$ Sawyer 1975

$\mathrm{W}=$ Whistler $1976 \mathrm{c}$

\section{Patwin (P)}

Forms marked as $\mathrm{P}$ are common to all Patwin dialects. Dialects are indicated following the $\mathrm{P}$ as follows:

$\mathrm{C}=$ Cortina Hill Patwin

$\mathrm{CC}=$ Cache Creek Hill Patwin (aka Rumsey)

$\mathrm{H}=$ all Hill Patwin dialects or unspecified Hill Patwin dialect

$\mathrm{K}=$ Kabalmem Hill Patwin (aka Lodoga)

$\mathrm{R}=$ River Patwin

$\mathrm{T}=$ Lake County Hill Patwin (aka Tebti)

Forms unmarked as to source are from Whistler 1975-1979, unless otherwise marked as from a particular publication. Other sources are identified as follows: 
$\mathrm{B}$ and $\mathrm{U}$ are from Bright and Ultan 1970, an alphabetized computer printout of lexical items collected in the field by Bright and Ultan. This printout uses the following unexplained abbreviations for dialects: A, H, L, R, T. My best guess is that these may represent: $\mathrm{H}=$ Hill, $\mathrm{L}=$ Lodoga (Whistler's $\mathrm{K}$ ), $\mathrm{R}=$ River and $\mathrm{T}=$ Tebti. "A" may represent Cortina Hill Patwin, although I do not know why the letter A was chosen. It does not appear to stand for "all."

Forms marked M are from Merriam 1903-1936.

\section{South Patwin (SP)}

Forms marked SP are from Whistler $1976 \mathrm{e}$ or 1980 as indicated. Other forms are marked for source as follows:

$\mathrm{A}=$ Arroyo de la Cuesta 1821, using English glosses provided by Golla in a worksheet accompanying Golla 1996.

$\mathrm{G}=$ von Gerolt's retranscription of Arroyo (Gerolt 1830)

M = Merriam's South Patwin vocabulary schedule 1906, 1917

$\mathrm{V}=$ Vocabulary obtained by J. Alden Mason from Platon Vallejo (in Kroeber 1932), using English glosses provided in the worksheet accompanying Golla 1996.

\section{Comparisons with Other Languages}

Resemblances in other languages cited along with reconstructions by no means imply a suggestion of genetic relationship. It is up to the reader to decide if these forms are potentially genetically related, borrowed, diffused, onomatopoetic, or coincidence. No thorough search for resemblances has been conducted. The forms listed are those cited by others in comparative studies or noticed by the author in reading a variety of publications.

Alsea, Hanis, Siuslaw and Wasco comparisons are from Golla 1997 unless otherwise noted.

Uto-Aztecan and Proto-Uto-Aztecan (PUA) forms are from Miller 1967 unless otherwise indicated.

Proto-Mayan (PMy) forms and citations from Mayan daughter languages are from Brown 1990. In these forms, ${ }^{*} t^{y}$ represents a palatized apical stop.

Maidun, Miwok, Costanoan and Yokuts forms are from Callaghan 2001 unless otherwise indicated. Callaghan uses the following abbreviations:

$\mathrm{Ceb}=$ Northern Costanoan: East Bay (Chocheno)

Csf $=$ Northern Costanoan: San Francisco

Csjb $=$ Southern Costanoan: Mutsun

Cscr $=$ Northern Costanoan: Santa Cruz

$\mathrm{PCo}=$ Proto-Costanoan

$\mathrm{PCos}=$ Proto-Southern-Costanoan 
Mie $=$ Eastern Miwok

Mil = Lake Miwok

Mim = Marin Miwok

Mins $=$ Northern Sierra Miwok

Mip $=$ Plains Miwok

Mis = Sierra Miwok

PMi = Proto-Miwok

PMie $=$ Proto-Eastern-Miwok

PMis $=$ Proto-Sierra-Miwok

PMiw = Proto-Western-Miwok

$\mathrm{PU}=$ Proto-Utian

PY $=$ Proto-Yokuts

PYgen $=$ Proto-General-Yokuts

PYn = Proto-Northern-Yokuts

PYnim = Proto-Nim-Yokuts

PYnv = Proto-Northern-Valley-Yokuts

$\mathrm{PYbv}=$ Proto-Buena-Vista-Yokuts

$\mathrm{Ykr}=$ Kings River Yokuts

$\mathrm{Yn}=$ Northern Yokuts

$\mathrm{Yv}=$ Valley Yokuts

Mk = Konkaw

$\mathrm{Mm}=$ Maidu

Mn $=$ Nisenan

$\mathrm{PM}=$ Proto-Maidun

\section{Symbols Used by Other Sources}

C. Hart Merriam uses English spelling with some modifying diacritics for vowels; e.g., $\bar{a}=\left[e^{\cdot}\right]$, ah $=[\mathrm{a}]$ or $[\mathrm{a} \cdot]$, oo $=[\mathrm{u}]$ or $[\mathrm{u} \cdot], \overline{\mathbf{1}}=[\mathrm{i}]$. An apostrophe indicates stress or glottalization depending on placement.

\section{Nomlaki}

\section{Barrett 1908}

$\overline{\mathrm{i}}, \overline{\mathrm{e}}, \overline{\mathrm{u}}, \overline{\mathrm{o}}$ represent the corresponding short or long vowels

The exclamation point represents glottalization

$\mathrm{t} \cdot=\mathrm{t}$ or $\mathrm{t}^{\mathrm{h}}$

$\mathbf{t} \cdot \mathbf{c}=\check{\mathbf{c}}$

$\mathrm{L}=1$

$\mathrm{c}=\mathrm{s}$ (Barrett describes his symbol "c" as representing an "open pre-palatal surd ... similar to English sh" (1908: 52). As there is no [ธ̌] in Wintun, the symbol is taken to refer to the alveolar fricative [s]. 
Blankenship and Wenger 1978

$\mathrm{c}=\check{\mathrm{c}}$

$\mathrm{kL}=\mathrm{q}^{\prime}, 1$

$\mathrm{tl}, \mathrm{L}=1$

The symbol "3" used in this source to represent short [a] has been replaced with a.

$$
\begin{aligned}
& \text { Curtis } 1924 \\
& \hat{\mathrm{a}}=0 \text { or } \mathrm{a} \\
& \mathrm{ch}=\check{\mathrm{c}} \\
& \mathrm{ch} !=\check{\mathrm{c}} \\
& \mathrm{hl}=1 \\
& \check{\mathrm{e}}=\mathrm{e} \text { (short) } \\
& \mathrm{p} \cdot=\mathrm{p} \\
& \mathrm{k}=\mathrm{k} \text { or } \mathrm{q} \\
& \mathrm{k} \cdot \mathrm{q} \\
& \mathrm{t} \mathrm{l}=\lambda,
\end{aligned}
$$

Dixon \& Kroeber 1907

$\mathrm{L}=1$

\section{Goldschmidt 1951}

tc $=\check{c}$ or $\check{c}^{\prime}$

tc' $^{\prime}=\check{\mathrm{c}}$ '

$\mathrm{tl}=\mathrm{l}$ or $\lambda$

$\hat{\mathrm{e}}=\mathrm{i} \cdot$ ?

' $t=t$ '?

$\hat{\mathrm{e}}=\mathrm{e}$

$\mathrm{khl}=\mathrm{l}$

$\dot{\mathbf{o}}=\mathbf{0}$

$\overline{\mathbf{u}}=\mathbf{u} \cdot$

$\check{\mathbf{o}}=\mathbf{o}$

$\hat{\mathrm{i}}=\mathrm{i}$.

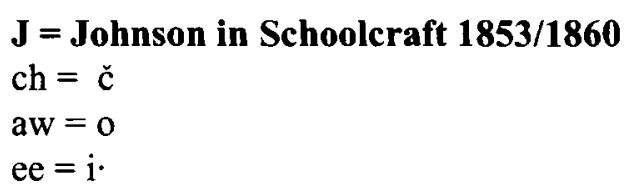

\section{Kroeber 1932}

$\mathrm{L}=$ ł

\section{South Patwin}

$\mathrm{j}=\mathrm{h}$ 


$$
\begin{aligned}
& \text { hu }=w \\
& \text { ch }=\check{c} \\
& \text { gl }=1 \\
& \mathrm{c}=\mathrm{s}
\end{aligned}
$$

Arroyo/Gerolt 1830

tsch $=\check{c}$

$$
\begin{aligned}
& \text { Mason/Vallejo } \\
& \text { tc }=\check{c} \\
& v=u \text { or } o ?
\end{aligned}
$$


